\title{
ПРОФЕСІЙНЕ ДІЛОВЕ СПІЛКУВАННЯ: СТАНОВЛЕННЯ І РОЗВИТОК ПОНЯТТЯ
}

Зотова-Садило О. Ю. Професійне ділове спілкування: становлення і розвиток поняття.

У статті розкривається питання щодо становлення і розвитку поняття «професійне ділове спілкування», обгрунтовується його сутність, структура та специфіка вияву.

Ключові слова: професійне ділове спілкування, фахівець економічного профілю, специфічні характеристики, комунікативний процес, ділова бесіда, переговори, ділові стосунки.

Зотова-Садыло Е. Ю. Профессиональное деловое общение: становление и развитие понятия.

В статье рассматриваются вопросы, связанные с развитием понятия «профессиональное деловое общение», обосновывается его сущность, структура и специфика проявления.

Ключевые слова: профессиональное деловое общение, специалист экономического профиля, специфические характеристики, коммуникативный процесс, деловая беседа, переговоры, деловые отношения.

Zotova-Sadylo H. Y. Professional business communication: the development of the concept.

The article focuses attention on the issues associated with the development of «professional business communication» concept, its structure and specific features.

Key words: professional business communication, specialist of economics, specific characteristics of the communicative process, business conversation, negotiations, business relations.

Сучасне українське суспільство потребує високоосвічених спеціалістів, які б могли творчо використовувати набуті знання для оптимального розв'язання завдань професійної діяльності та мали високий рівень культури й техніки спілкування. Ураховуючи вимоги Болонської декларації та Європейської довідкової системи, особливої цінності набуває здатність фахівця, зокрема, економіста, до комунікації, у тому числі ділової, що забезпечує успішні партнерські стосунки.

Зростити саме такого спеціаліста є нагальною проблемою вищої школи, оскільки донині вона повною мірою не розв'язана - це актуалізує наукові дослідження з проблеми формування ділового спілкування майбутніх фахівців економічного профілю.

3 огляду на означене вище метою статmі є обгрунтування теоретичних засад поняття «професійне ділове спілкування» і його структурно-функціональних особливостей.

У сучасній науці співіснують два терміни, кожен 3 яких відображає сутнісні грані спілкування людей, які співпрацюють у певній галузі, а саме: «ділове спілкування» та «професійне спілкування». Ми вважаємо за доцільне об'єднати ці два словосполучення у єдине ціле, оскільки будь-яка справа має здійснюватись професійно, щоб отримати кінцевий результат. Під час діяльності, розв'язуючи проблеми, партнери спілкуються у професійному аспекті. Відбувається закономірний процес: успіх у колективній справі досягає свого апогею лише за умови продуктивного, професійно спрямованого ділового спілкування.

Слід зазначити, що словосполучення «професійне ділове спілкування» більшість дослідників не використовує, але, як видно із контексту їхніх наукових доробків, поняття «ділове спілкування» передбачає спілкування на фаховому рівні, а критерієм якості виконання справи є професіоналізм, саме тому можна вважати, що мається на увазі суто професійне ділове спілкування. Варто звернути увагу на те, що професійне ділове спілкування - це багатоаспектне явище, тому в науці підходи до визначення його сутності різноманітні. Зокрема філософський аспект професійного ділового спілкування висвітлено у дослідженнях українських та зарубіжних науковців, а саме: М. Дмитренко, 
О. Ковнєрова, В. Лавриненка, Г. Чайки та інших [5; 9; 13; 17]. Варто додати, що саме словосполучення «професійне ділове спілкування» більшість дослідників не використовують, але як видно із контексту їхніх наукових доробків, ділове спілкування передбачає професійне як спілкування на фаховому рівні і як критерій якості виконання справи - професіоналізм.

Щодо персонального трактування аналіз робіт показав, що М. Дмитренко співвідносить розвиток ділового спілкування 3 економічним розвитком суспільства. Зазначений феномен, на думку вченої, охоплює всі різновиди підприємницької діяльності, менеджменту, організаційної роботи та соціокультурної діяльності, результатом якої $\epsilon$ «креативний продукт» [5, с. 55]. Він обов'язково містить у собі процедури чи фрагменти соціальної діяльності. Інші науковці - О. Ковнєров, В. Лавриненко, Е. Островський, Г. Чмут, Т. Чайка піднімають питання про стосунки між діловими партнерами. Науковці декларують ділове спілкування як вид соціальних стосунків, опосередкований будь-якою діяльністю, змістом яких є діло або справа [9; 13; 17]. Означений феномен забезпечує плідні умови для співробітництва та сприяє досягненню значущих для обох партнерських сторін цілей [13].

Російський науковець Б. Зельдович визначає ділове спілкування як «..процес взаємозв'язку та взаємодії, в якому відбувається обмін діяльністю, інформацією та досвідом, що передбачає досягнення певного результату, розв'язання конкретної проблеми чи реалізацію визначеної цілі» [8, с. 15]. Автор зазначає підпорядкованість особистих інтересів інтересам справи, які виконують першочергову роль у цьому виді спілкування. Ми цілком згодні з позицією науковця.

Білоруська вчена О. Баєва визначає ділове спілкування як «...вид міжособистісного спілкування, спрямований на досягнення якої-небудь предметної домовленості» [1, с. 8]. До специфічних ознак ділового спілкування вона відносить уміння розбудовувати стосунки з різними людьми, досягаючи максимальної ефективності ділових контактів, та зацікавленість співбесідників у корисності один одному. Дійсно, для професійного ділового спілкування спеціалістів, зокрема економічного профілю, останнє є особливо актуальним, оскільки за усіх можливих варіантів розвитку ділової взаємодії висококваліфіковані фахівці мають орієнтуватися на захист інтересів справи й отримання зиску.

Вітчизняний науковець Ф. Хміль досліджує ділове спілкування в аспекті управлінської діяльності. Він надає дефініцію зазначеного феномену, акцентуючи увагу на його комунікативному аспекті, який є «...суттєвим складником спілкування» та «полягає в обміні інформацією, завдяки якому керівник одержує необхідні для прийняття ефективних рішень відомості і доводить свої рішення до підлеглих теж у формі інформації» [16, с. 13]. Останнє твердження свідчить про наявну в науці тенденцію конкретизувати та диференціювати такі поняття як «спілкування», «ділове спілкування», «професійне ділове спілкування» та «ділова комунікація». Нам імпонує ця позиція, оскільки дослідник грунтовно доводить, що ділове спілкування є загальне за змістом, багатоаспектне явище, одним із типів якого є ділова комунікація.

Вагомим внеском для розв'язання проблеми професійного ділового спілкування $\epsilon$ обгрунтування вченою О. Рембач дефініції ділового спілкування. Згідно 3 поглядом автора, воно «...становить складний процес встановлення і розвитку професійних контактів, зумовлений потребами виконання виробничих функцій i типових завдань професійної діяльності. Воно передбачає обмін інформацією, вироблення єдиної стратегії взаємодії, сприйняття і розуміння іншої людини» [14, с. 66]. У цілому ми погоджуємося 3 цим визначенням, але вважаємо необхідним доповнення в аспекті професійності.

На нашу думку, професійне ділове спілкування - це процес цілеспрямованого обміну специфічною професійною інформацією між соціальними суб'єктами, що має на меті здійснення фахово зумовленого акту в інтересах обох суб'єктів. При цьому особистісний чинник відіграє мінімальну роль у вищезгаданому процесі. 
Для розбудови структури зазначеного феномену було проаналізовано представлені в науці класифікації видів і типів спілкування. Так, О. Бодальов, С. Максименко, В. Соловієнко, Г. Чайка диференціюють спілкування за такими критеріями [2; 12; 17]: специфікою суб'єктів чи контингентом учасників (міжособистісне, особистісно-групове, міжгрупове); за кількістю суб'єктів (самоспілкування, міжособистісне та масові комунікації); за характером (опосередковане й безпосереднє, діалогічне й монологічне); за цільовою спрямованістю (анонімне, функціонально-рольове, інформативне, неформальне); за протяжністю (короткотривале - довготривале); за ступенем завершеності; за бажаністю.

Аналіз зазначеної наукової літератури підтверджує, що вищезазначені критерії $\epsilon$ типовими для характеристики ділового спілкування.

За поданими критеріями вирізняються види спілкування, що має рацію. Науковці Т. Андрєєва, Б. Зельдович, Л. Столяренко залежно від техніки і цілей виокремлюють формальне спілкування («контакт масок»), формально-рольове спілкування (із регламентованим змістом і засобами), формально ввічливе (світське), маніпулятивне (метою є отримання зиску), духовне міжособистісне, ділове (спрямоване на досягнення обопільно вигідного результату) [7; 8; 15].

У діловому аспекті вітчизняні дослідники Т. Гриценко, С. Гриценко, Т. Іщенко, Т. Мельничук, М. Колтунова диференціюють спілкування за [6; 10]: формами мовлення (усне - письмове); кількістю учасників (діалогічне - монологічне); відстанню (контактне дискантне); наявністю технічних засобів (безпосереднє - опосередковане); глибиною стосунків (товариське, дружнє - формально поверхове).

Сфера здійснення спілкування є надзвичайно різноманітною: на роботі, у домашньому побуті, крамниці, банку, навчальному закладі, навіть у громадському транспорті тощо. Проте особливість професійного спілкування полягає саме у звуженні сфери його застосування. Говорячи про ПДС, ми маємо на увазі усну чи письмову форму обміну специфічною інформацією із вживанням спеціальних термінів та професіоналізмів. Мета ПДС, зокрема економістів - це розв'язання фахово спрямованого завдання чи отримання комерційного зиску. Специфічною ознакою зазначеного феномену є нехтування критерієм «бажаності» [6]. Для ділової людини є неконструктивним підхід вибору партнера за особистими уподобаннями. Важливим є предмет спілкування (справа) і прийнятний результат. Саме справа, діло за фахом є першопричиною виникнення феномену ПДС.

Наступна особливість професійного ділового спілкування полягає в його колективній спрямованості. Дослідження Л. Виготського довели, що людина реалізує функцію спілкування навіть, коли залишається на самоті [4]. Проте за наявності лише одного учасника втрачається сенс саме в ПДС, оскільки апріорі воно передбачає обмін фахово орієнтованою інформацією між двома чи більше суб'єктами і має на меті розв'язання специфічних завдань, зумовлених приналежністю індивідів до певних професійних груп. Отже, для повноцінного професійного ділового спілкування необхідні суб'єкти взаємодії.

Фахове спрямування ПДС зумовлює відмінності у підготовці майбутніх спеціалістів. Наприклад, майбутнім економістам важливо оволодіти навичками ведення ділової бесіди, переговорів, прес-конференцій, ділової переписки тощо, тоді як у підготовці інженерівпрограмістів зазначені навички не відіграють провідної ролі. У професійній комунікації програмістів превалюють знаки та формули, їм має бути притаманний лаконізм i фактологічна достовірність. Отже, особливістю ПДС є диференціація професійних умінь $\mathrm{i}$ навичок фахівців різного профілю.

Виходячи 3 напрацювань, які представлені у сучасній науці та 3 власних міркувань, вважаємо за доцільне класифікувати професійне ділове спілкування за такими основними критеріями: специфікацією (економічне, юридичне, педагогічне, медичне тощо); формою викладу тексту чи повідомлення (усне - письмове, опосередковане - безпосереднє); кількістю учасників (діалог, полілог); орієнтованістю на часові та просторові еквіваленти (миттєве - віддалене у часі досягнення результату, локальне - глобальне, фрагментарне масштабне); мовним аспектом (іншомовне професійне спілкування чи рідною мовою); 
ситуацією (у процесі професійної діяльності чи поза неї, спонтанне - підготоване); тривалістю і глибиною (короткочасне - тривале, поверхове - глибинне); ефективністю (позитивний, нейтральний чи негативний результат спілкування); статусом (по горизонталі - по вертикалі: продавець - покупець, керівник - підлеглий, клієнт службовець, між колегами); культурологічним аспектом (між представниками різних націй, релігійних конфесій, світоглядів, освіченості і вихованості різного рівня тощо).

Важливо диференціювати вимоги до компетентного комунікатора в полі професійного ділового спілкування. На наш погляд, фахівець у процесі ділової взаємодії для досягнення позитивного результату має виявляти: здатність розв'язувати проблему з партнерських позицій; навички активного слухання; багатий професійний словниковий запас; уміння розбудовувати міжособистісні й ділові стосунки на підгрунті взаєморозуміння та довіри; емпатійні здібності для створення рефлексивної атмосфери у процесі спілкування; відкриту позицію по відношенню до співрозмовника; креативність і гнучкість; конкретність і професіоналізм.

Цікавою є позиція Д. Камерона та Д. Таннена, які заявляють, що більшість з означеного комплексу вмінь та навичок краще розвинуті та виражені під час ділового спілкування жінок [18]. Дослідники аргументують свою думку тим, що особам жіночої статі від природи притаманні чутливість, емоційність, толерантність та в цілому вони більш сенситивні за чоловіки. Такий гендерний підхід певною мірою виправданий. Аргументом на його користь може бути факт, що у сфері обслуговування, секторі «паблік рілейшнз», мережевому маркетингу, де фахово орієнтоване компетентне спілкування $є$ визначальною умовою досягнення успіху, переважно жінки досягають значних результатів. Варто зауважити також, що гендерні відмінності у ПДС виявляються у стилістичних особливостях мовлення жінки (короткі - повні відповіді, частотність вживання емоційно забарвленої лексики, вставних слів і службових частин мови, застосування інструменту «пауза»), акцентуації на статусній приналежності, манері проводити інструктаж, специфіці невербального аспекту тощо. Проте не варто доводити своєрідність спілкування жінок та чоловіків до конфронтації - це лише один з чинників, що певною мірою впливають на продуктивність професійного ділового спілкування.

Специфіка професійного ділового спілкування виявляється також через його функції. Окрім трьох основних функцій спілкування - комунікативної, інтерактивної, перцептивної (за С. Максименко, В. Соловієнко [12]), наявні інші, що притаманні саме професійному діловому спілкуванню. Розглянемо більш детально три з них.

Перша - консолідуюча. За визначенням словника «...консолідація - це згуртування, об'єднання, зміцнення» [3, с. 306]. Так, правильно організоване ПДС об'єднує окремих індивідів у функціональні групи (партнерські пари, бригади, робочі групи, творчі об'єднання, динамічні групи, колективи тощо). Це уможливлює їх взаємодію в різних аспектах, забезпечує досягнення кінцевого результату через співпрацю учасників. Ці об'єднання різняться за кількісним та якісним показниками. Як зазначалося раніше, «справа» є тим базовим поняттям, що диференціює ПДС між іншими видами спілкування. I саме це визначає характер, терміни функціонування та ієрархічну структуру групи. Спілкування, в свою чергу - це «клей», який з'єднує окремі елементи та перетворює їх на єдиний функціональний організм. Так, студент вищого навчального закладу можливо, вперше вступає у суто професійне ділове спілкування із членами академічної групи, яке відбувається на підгрунті спільної справи навчання. Слід зазначити, що ПДС студентів, які навчаються за спеціальністю «Економіка підприємства», певною мірою різниться від ПДС студентів, які навчаються за спеціальністю «Банківська справа». Водночас, їхнє міжособистісне спілкування залишається подібним, оскільки студентів обох груп об’єднують вік, коло позанавчальних інтересів, спільні друзі тощо. Отже, консолідуюча функція ПДС реалізується через ділову взаємодію й обмін специфічною інформацією між суб' єктами, інтегрованими за принципом спільних професійних інтересів. 
Наступна, промотивна функція ПДС, є важливою для успішного існування й розвитку будь-якого підприємства. Словник визначає «промоушн» як сприяння реалізації певної ідеї; просування продукту на ринку [3]. Так, через засоби професійної комунікації реалізується мотивація працівників до продуктивної виробничої взаємодії, кар'єрного розвитку та зростання: означена функція ПДС знаходить вияв у постановці виробничого завдання, розбудові алгоритму його виконання, окресленні можливих варіантів удосконалення процесу. Формулювання специфічної мети, директиви щодо бажаних моделей поведінки та шляхів досягнення успіху передбачають наявність специфічних умінь і навичок у керівника та його підлеглих. Засоби професійної комунікації забезпечують конкурентоспроможність компанії. Без налагодження системних зв'язків між споживачем та виробниками неможливо гідно конкурувати у тій чи іншій галузі виробництва. Реклама та «паблік рілейшнз» $\epsilon$ життєво необхідними для здійснення бізнесу. За умови, що працівники компанії володіють на достатньому рівні навичками проведення презентацій, прес-конференцій, брифінгів, вони зможуть донести необхідну інформацію до споживача, гідно презентувати продукт чи послугу і в результаті досягнути професійного успіху. Окрім того, засоби професійної комунікації сприяють створенню та популяризації бренду компанії.

Нерідко фірмовий знак перетворює звичайний товар чи послугу на бренд, який легко впізнати у межах країни чи навіть поза іiі межами. Це надає змогу компанії-власнику продавати не окремий продукт, а групу товарів (послуг) під одним логотипом, i отримувати в декілька разів більший прибуток. Одним із провідних аспектів популяризації бренду $\epsilon$ опосередковане професійне ділове спілкування, наприклад, реклама в засобах масової інформації (on-line, на телебаченні, бігбордах, друкованих виданнях тощо).

Третя функція ПДС - регулювальна. Як відомо, одна 3 ключових характеристик успішного керівника - це його здатність спілкуватися. За підрахунками спеціалістів від 70 до $90 \%$ робочого часу він витрачає саме на комунікацію [11]. Сучасний ефективний менеджер не розв'язує виробничих завдань самотужки, а створює оптимальні умови для їх розв'язання. Отже, досконале володіння навичками спілкування є визначальним критерієм професіоналізму керівника. Продуктивне спілкування в системі «менеджер - підлеглий» уможливлює функціонування бізнес-організації на різних рівнях: внутрішньому, оскільки забезпечує реалізацію основних функцій менеджменту: плануючої, організаційної, стратегічної та контролюючої, i зовнішньому: між партнерськими компаніями, організацією та суспільством, підприємством та профспілками тощо). Від того, наскільки чітко та компетентно реалізується професійне ділове спілкування в означених контекстах, залежить рівень злагодженості регулювання діяльності бізнес-організації.

Отже, професійна комунікація є необхідним інструментом у виконанні фахових завдань i досягненні кар'єрних цілей для спеціалістів економічного спрямування. Специфічним для професійного ділового спілкування економістів $є$ : публічність (доповіді на нарадах, ведення переговорів, участь у прес-конференціях); демонстративність (презентації нового продукту чи послуги); аргументованість (переконливість аргументації надає змогу розв'язати проблему та досягти бажаного результату); психологічний аспект (уміння прихилити співбесідника до власної позиції); вправність у використанні як вербальних, так і невербальних засобів спілкування (ділові бесіди, переговорний процес, обговорення деталей угоди); ритуалізація комунікативного процесу (слідування нормам протоколу та етикету); дотримання етичних принципів; переконливість іміджу ділової людини.

Необхідність навчання майбутніх економістів спілкуватися професійно зумовлена тим, що вищевказані ознаки далеко не завжди притаманні побутовій повсякденній комунікації. Попередньо зазначені вміння не передаються на генетичному рівні, незначною мірою набуваються досвідом спілкування протягом життя, цьому необхідно цілеспрямовано навчатися. У суспільстві наявна потреба в конкурентоспроможних спеціалістах економічної галузі з високим рівнем культури професійної діяльності, одним із компонентів якої є професійне ділове спілкування. Переконані, що комплексний підхід до 
підготовки майбутніх економістів у цьому аспекті позитивно впливатиме на розвиток і формування їхніх професійних якостей.

Сучасні дослідження демонструють досить значні напрацювання у розв'язанні проблеми формування професійного ділового спілкування майбутніх фахівців. Водночас, аналіз показує неоднозначність концептуальних підходів до визначення структури, змістовних характеристик та особливостей вияву зазначеного феномену, що свідчить про складність цього явища. Наука послуговується термінами «ділове спілкування», «професійне спілкування» та «професійна комунікація», чиї дефініції багато в чому перекликаються одна $з$ одною. Незважаючи на деякі суперечності в підходах до окремих частковостей проблеми, науковці виявили типові критерії для характеристики ділового спілкування, диференціювали вербальну та невербальну складову зазначеного феномену й окреслили окремі специфічні показники ділового спілкування в економічній сфері. Варто зауважити, що саме теоретичний аспект залишається недостатньо розкритим і потребує більш детального вивчення. Однак, усе вище зазначене розширює спектр наукових даних стосовно ділового спілкування й створює передумови для уведення в науковий обіг терміну «професійне ділове спілкування» та відповідного обгрунтування.

У практичному плані нами здійснюється дослідження щодо формування професійного ділового спілкування майбутніх фахівців-економістів у цілісній системі гуманітарної підготовки.

\section{Література}

1. Баева О. А. Ораторское искусство и деловое общение: [учебное пособие]. - [2-е изд-е, испр.] / Ольга Абрамовна Баева. - Мн. : Новое знание, 2001. - 328 с. 2. Бодалев А. А. Психология общения. Избранные психологические труды / Алексей Александрович Бодалев. - М. : Институт практической психологии, Воронеж : НПО «Модек», 1996. - 256 с. 3. Большой словарь иностранных слов / [сост. Москвин А.Ю.]. - М. : Центрполиграф, 2003. - 815 с. 4. Выготский Л. С. Собрание сочинений в 6 т. / Лев Семенович Выготский. - М. : Педагогика, 1983. - Т.3 : Проблемы развития психики. - 1983. - 368 с. 6. Дмитренко М. И. Деловое общение как феномен социальной действительности : дис. ... кандидата философ. наук : 09.00.03 / Дмитренко Мария Иосифовна. Хар., 2005. - 161 с. 7. Етика ділового спілкування: [навчальний посібник] / [Гриценко Т.Б., Гриценко С.П., ІщенкоТ.Д. та ін.]; за ред. Т.Б.Гриценко та ін. - К. : Ценр учбової літератури, 2007. - 344 с. 8. Етика та психологія ділових відносин: [навчальний посібник] / [Андрєєва Т.С., Бутенко О.П., Опікунова Н.В. та ін.]; за ред. проф. Т.Є.Анрєєвої. - Харків : Бурун Книга, 2004. - 144 с. 9. Зельдович Б. 3. Деловое общение: [учебное пособие] / Борис Захарович Зельдович. - М. : Издательство «Альфа-пресс», 2007. - 456 с. 10. Ковнеров А. Е. Коммуникативная философия как одна из методологических основ профессиональной этики [Электронный ресурс] / А. Е.Ковнеров // Ноосфера і цивілізація : електронне наукове видання - Донецьк : 2008. - Вип.6 (9). - Режим доступу до журналу: http:// www.nbuv.gov.ua/ portal/Soc_Gum/Niz/2008_9/Kovnerov.htm 11. Колтунова М. В. Язык и деловое общение : [учебное пособие] / Мария Викторовна Колтунова. - М. : Экономика, 2000. - 152 с. 12. Короткова Е. С. Психотехнологии общения менеджера : [учебное пособие] / Е.С. Короткова, О. С. Васильева. - Ростов-на-Дону, 2008. - 104 с. 13. Максименко С. Д. Загальна психологія : навчальний посібник / Сергій Дмитрович Максименко, Валентин Олександрович Соловієнко. - К. : МАУП, 2000. - 256 с. 14. Психология и этика делового общения: [учебник для вузов] / [под ред. проф. В. Н. Лавриненко]. - [4-е изд.]. - М .: ЮНИТИ-ДАНА, 2005. 415 c. 15. Рембач О. О. Формування культури ділового спілкування майбутніх міжнародниківаналітиків у ВНЗ: дис. ... канд. пед. наук : 13.00 .04 / Ольга Олександрівна Рембач. - Вінниця, 2005. 369 с. 16. Столяренко Л. Д. Психология делового общения и управления: [учебник] / Людмила Дмитриевна Столяренко. - [Изд-е 4-е]. - Ростов-на-Дону : «Феникс», 2005. - 409 с. 17. Хміль Ф. І. Ділове спілкування : підручник / Федір Іванович Хміль. - К. : «Академвидав», 2004. - 280 с. 18. Чмут Т. К. Етика ділового спілкування: [навчальний посібник] / Т. К. Чмут, Г. Л. Чайка. - K: Вікар, 2003. - 223 c. 19. Cameron D. Gender and Language Ideologies // The Handbook of Language and Gender: scientific articles edited by Janet Holmes and Miriam Meyerhoff / Cameron Deborah. Blackwell Publishing Ltd, 2003. - P. 447-468. 